\title{
Game Eedukasi Simulasi Penyemprotan Cairan Disinfektan Berbasis 2D Dalam Upaya Pencegahan Wabah Covid-19
}

\section{Lingga Sabdha Auraly ${ }^{1}$, Andi $^{2}$, Agis Maulana Robani ${ }^{3}$, Fadhil Muhamad Basysya ${ }^{4}$, Raditya Danar Dana ${ }^{5}$}

${ }^{1}$ Sistem Informasi; STMIK IKMI CIREBON; JI. Perjuangan No.10B, Karyamulya, Kec. Kesambi, Kota Cirebon, Jawa Barat 45131, 0231-490480; e-mail: info.ikmicirebon@gmail.com.

2 Teknik Informatika; STMIK IKMI CIREBON; JI. Perjuangan No.10B, Karyamulya, Kec. Kesambi, Kota Cirebon, Jawa Barat 45131, 0231-490480; e-mail: andiandi20@gmail.com.

${ }^{3}$ Sistem Informasi; STMIK IKMI CIREBON; JI. Perjuangan No.10B, Karyamulya, Kec. Kesambi, Kota Cirebon, Jawa Barat 45131, 0231-490480; e-mail: info.ikmicirebon@gmail.com.

${ }^{4}$ Sistem Informasi; STMIK IKMI CIREBON; JI. Perjuangan No.10B, Karyamulya, Kec. Kesambi, Kota Cirebon, Jawa Barat 45131, 0231-490480; e-mail: info.ikmicirebon@gmail.com.

${ }^{5}$ Manajemen Informatika; STMIK IKMI CIREBON; JI. Perjuangan No.10B, Karyamulya, Kec. Kesambi, Kota Cirebon, Jawa Barat 45131, 0231-490480; e-mail: info.ikmicirebon@gmail.com.

* Korespondensi: e-mail: andiandi20@gmail.com

Diterima: 15 April 2021; Review: 21 April 2021; Disetujui: 26 April 2021, 166-175

Cara sitasi: Auraly Is, Andi, Robani AM, Basysyar FM, Dana RD. 2021. Game Eedukasi Simulasi Penyemprotan Cairan Disinfektan Berbasis 2D Dalam Upaya Pencegahan Wabah Covid-19. Informatics for Educators and Professionals. Vol (5) No.2:Hal: 166-175

\begin{abstract}
Abstrak: Pada pertengahan tahun 2020 ini telah muncul sebuah wabah virus yang disebut dengan virus corona, atau dalam bahasa medis disebut COVID-19 yang telah memakan banyak korban jiwa, salah satu cara yang dilakukan agar terhindar dari pandemic COVID-19 ini yaitu dengan melakukan penyemprotan cairan desinfektan, namun karena kurangnya sosialisasi tentang penyemprotan disinfektan ini, banyak orang yang belum mengetahui akan pentingnya penggunaan cairan desinfektan ini, dengan adanya masalah ini mahasiswa teknik informatika dapat berperan penting untuk melakukan sosialisasi tentang penyemprotan disinfektan. Game adalah sebuah bentuk karya seni dimana peserta yang disebut pemain, membuat keputusan untuk mengelola sumber daya yang dimilikinya melalui benda di dalam game demi mencapai tujuan, Dengan pendalaman teori perancangan game edukasi dan cairan desinfektan maka dapat membuat game edukasi manfaat cairan desinfektan. Inti dari permainan ini player harus mengetahui jenis-jenis cairan desinfektan yang digunakan, mengetahui seperti apa pakaian APD yang digunakan, dan memahami bagaimana cara melakukan penyemprotan cairan disinfektan, Dalam penelitian ini game engine yang akan digunakan untuk merancang game edukasi ini yaitu Unity 3D, game engine unity 3D dipilih berdasarkan materi yang telah dipelajari selama proses perkuliahan, dan sudah dikuasai dalam pengoperasiannya, tahapan dalam pembuatan game sendiri diantaranya yaitu, menentukan alur game, merancang storyboard, pembuatan desain karakter dan layout, scripting atau pembuatan script, dan terakhir evaluasi game. Ruang lingkup yang akan dilakukannya penelitian yaitu pada kalangan anak-anak dan remaja, pelajar dan mahasiswa, Tahapan yang akan dilakukan yaitu pertama merancang game edukasi terlebih dahulu, lalu merancang kuesioner yang akan diisi oleh responden, berikutnya dilakukan penyuluhan dan sosialisasi game pada responden, Berdasarkan hasil dari uji hipotesis, dengan dikembangkannya simulasi penyemprotan berbasis game edukasi 2D dapat mendukung dalam upaya mengoptimalisasi pencegahan penyebaran covid-19
\end{abstract}

Kata kunci: Covid 19, Datamining, Game, Animasi, Penanganan 


\begin{abstract}
Abstract- In mid-2020, a virus outbreak called the corona virus, or in medical language is called COVID-19, has claimed many lives, one way to avoid this COVID-19 pandemic is by spraying disinfectant liquid. However, due to the lack of socialization about this disinfectant spraying, many people do not know the importance of using this disinfectant liquid. With this problem, informatics engineering students can play an important role in socializing disinfectant spraying. Games are a form of art in which participants who are called players make decisions to manage their resources through objects in the game to achieve their goals. By deepening the theory of educational game design and disinfecting liquids, it can make educational games the benefits of disinfectant liquids. The essence of this game is that players must know the types of disinfectant liquid used, know what PPE clothes are used, and understand how to spray disinfectant liquid. In this study, the game engine that will be used to design this educational game is Unity $3 D$, a game. The $3 D$ unity engine is chosen based on the material that has been studied during the lecture process, and has been mastered in its operation, the stages in making the game itself, namely, determining the game flow, designing the storyboard, making character and layout designs, scripting or making scripts, and finally evaluating the game. The scope of the research will be carried out, namely among children and adolescents, students and university students, the stages to be carried out are first designing educational games, then designing a questionnaire to be filled in by respondents, then counseling and socializing games to respondents. the results of hypothesis testing, with the development of a spray simulation based on a $2 D$ educational game, it can support efforts to optimize the prevention of the spread of covid-19.
\end{abstract}

Keywords : Covid 19, Datamining, Game, Animation, Handling

\title{
1. Pendahuluan
}

Pada pertengahan tahun 2020 muncul wabah virus yang disebut dengan virus Corona, atau dalam bahasa medis disebut COVID-19 yang telah memakan banyak korban jiwa. Virus COVID-19 ini pertama kali muncul pada salah satu wilayah yang terletak di negara cina pada akhir tahun 2019, dari awal ditemukannya hingga sampai saat ini yang telah menyebar keseluruh dunia, dan salah satu Negara penyebaran virus COVID-19 ini yaitu Indonesia. Dengan munculnya pandemic Virus COVID-19 menimbulkan masalah yang besar, meskipun di Indonesia belum memberlakukan lockdown atau isolasi Negara, tetapi telah melakukan isolasi wilayah sampai pembatasan sosial berskala besar atau (PSBB). Salah satu aspek penting yang merasakan dampak dari adanya pemberlakuan PSBB ini yaitu pada dunia pendidikan, seluruh yayasan pendidikan di Indonesia memberlakukan sistem pembelajaran berbasis daring atau belajar online dari rumah dengan memanfaatkan media informasi yang ada. Salah satu cara yang dilakukan untuk terhindar dari pandemic COVID-19 ini yaitu dengan melakukan penyemprotan cairan desinfektan, namun karena kurangnya sosialisasi tentang penyemprotan disinfektan ini, banyak orang yang belum mengetahui akan pentingnya penggunaan cairan desinfektan ini, dengan adanya masalah ini mahasiswa teknik informatika dapat berperan penting untuk melakukan sosialisasi tentang penyemprotan disinfektan.

Berikut daftar kasus penyebaran covid-19 di Indramayu yang diambil dari media online ANTARNEWS.CM, dengan berdasarkan konfirmasi dari juru bicara penanganan covid-19 kabupaten Indramayu Deden Bonni Koswara pada hari Sabtu 13 Januari 2021, bisa dilihat pada tabel di bawah ini:

Tabel 1 Daftar Kasus Covid-19 Di Indramayu

\begin{tabular}{|c|c|c|c|}
\hline $\begin{array}{c}\text { Total } \\
\text { Kasus }\end{array}$ & Sembuh & $\begin{array}{c}\text { Mening } \\
\text { gal }\end{array}$ & $\begin{array}{c}\text { Dalam } \\
\text { Perawatan }\end{array}$ \\
\hline 2.301 & 1.673 & 89 & 539 \\
\hline
\end{tabular}

Sumber: ANTARNEWS.COM (2021)

Mengacu pada tabel 1 jumlah pasien meninggal lebih rendah dibandingkan dengan jumlah pasien yang sembuh dari covid-19, itu artinya pandemik bisa dilawan dengan mengikuti anjuran dari pemerintah dan selalu menjaga pola hidup bersih dan sehat. Permasalahan 
selama ini yaitu dapat menurunkan tingkat penyebaran covid-19 di Indramayu yang mencapai angka lebih dari 2000 kasus, dengan judul laporan yang dibuat dapat memberikan pemahaman dan pengetahuan terhadap masyarakat akan pentingnya cairan desinfektan ini, dengan banyaknya masyarakat yang memahami akan pentingnya cairan desinfektan ini maka bisa mengurangi total kasus covid-19.

Berdasarkan pada studi di lapangan, saat ini game mobile banyak diminati oleh kalangan anakanak, remaja, ataupun orang dewasa, namun game mobile yang sering dimainkan tidak begitu baik dan memberikan manfaat kepada para pemainnya [1]. . Game atau permainan adalah sesuatu yang dapat dimainkan dengan aturan tertentu sehingga ada yang menang dan ada yang kalah, biasanya dalam konteks tidak serius dengan tujuan refreshing. game edukasi adalah salah satu bentuk game yang dapat berguna untuk menunjang proses belajar-mengajar secara lebih menyenangkan dan lebih kreatif, dan digunakan untuk memberikan pengajaran atau menambah pengetahuan penggunanya melalui suatu media yang menarik. Simulasi secara sederhana dapat diartikan sebagai proses peniruan. Simulasi adalah tiruan dari fasilitas atau proses dari suatu operasi, biasanya menggunakan komputer. Simulasi adalah suatu proses peniruan dari sesuatu yang nyata beserta keadaan sekelilingnya (state of affairs), aksi melakukan simulasi ini secara umum menggambarkan sifat-sifat karakteristik kunci dari kelakuan sistem fisik atau sistem yang abstrak tertentu.

Sosial distancing bahkan banyak juga yang bemberlakukan lockdown tak terkecuali Indo nesia, diindonesia telah memberlakukan pembatasan sosial bersekala besar yang bertujuan untuk memutus ratai penyebaran virus ini. Meskipun virus ini sangat berbahaya dengan melakukan pencegahan yang dianjurkan oleh pemerinta resiko tertularnya oleh virus covid-19 dapat dihindari, diantaranya yaitu dengan mengurangi aktifitas diluar rumah, tidak melakukan kontak fisik secara langsung dengan orang lain, mengenakan masker ketika keluar rumah, menerapkan pola hidup bersih dan sehat, rajin mencuci tangan memakai sabun sebelum dan setelah beraktifitas, dan melakukan penyemprotan cairan disinfektan disetiap sudut rumah dan seluruh wilayah, dengan upaya tersebut kita bisa terhidar dari virus covid-19 [3]. Dengan menggabungkan teori perancangan game dan terjadinya pandemic covid-19 ini, penulis ingin menciptakan game edukasi yang tidak hanya mengutaakan kesenangan dalam memainkannya tapi dapan memberikan pengetahuan terhadap para pemainnya, pengetahuan yang akan diterapkan dalam game ini yaitu tentang manfaat cairan disinfektan [4] dan memberikan pengetahuan apa saja bahan yang dapat digunakan untuk dijadikan cairan disinfektan. Game Engine adalah mesin permainan yang merupakan sebuah sistem yang dirancang untuk penciptaan dan pengembangan video game, game engine adalah komponen software inti dari sebuah video game, game engine biasanya menangani perenderan grafik dan teknologi penting lainnya, tetapi juga memungkinkan dalam menangani fungsi tambahan seperti kecerdasan buatan, pendeteksian tubrukan antara objek game dengan benda lainnya. Sebuah game engine dibagi lagi menjadi dua bagian besar yaitu API dan SDK, API (Applicaiton Programming Interfaces) adalah bagian operating system, services dan libraries yang diperlukan untuk memanfaatkan beberapa feature yang diperlukan. Dalam hal ini contohnya DirectX, sementara SDK adalah kumpulan dari libraries dan API yang sudah siap digunakan untuk memodifikasi program yang menggunakan operating system dan services yang sama, biasanya, game engine menyertakan keduanya.

Dengan melakukan pendekatan kepada masyarakat melalui game edukasi penyemprotan disinfektan ini bisa kita jadikan sebagai media untuk mensosialisasikan pentingnya cairan disinfektan, dengan mendesain game edukasi tentang penyemprotan disinfektan yang menarik sehinga bisa diterima dengan mudah dikalangan anak-anak maupun orang dewasa, melalui game edukasi penyampaian akan pentingnya disinfektan tidak terasa monoton dan tidak membosankan dibandingkan jika disampaikan dengan secara lisan maupun tulisan [5].

\section{Metode Penelitian}

Pendekatan yang digunakan dalam penelitian ini adalah metode penelitian dan pengembangan (Research and Development), Research and Development adalah metode penelitian yang digunakan untuk menghasilkan produk tertentu dan menguji keefektifan produk tersebut, menghasilkan produk tertentu menggunakan penelitian yaitu analisis kebutuhan dan pengujian efektivitas produk, penelitian diperlukan untuk menguji keefektifan produk tersebut [6]. Oleh karena itu metode yang digunakan dalam penelitian ini menggunakan Research and 
Development (R\&D) yang merupakan metode yang saling berhubungan antara satu tahap dengan tahap lainnya, sedangkan penelitian pengembangan menurut Seels \& Richey didefinisikan sebagai berikut: "Developmental research, as opposed to simple instructional development, has been defined as the systematic study of designing, developing and evaluating instruksional programs, processes and products that must meet the criteria of interval consistency and effectiveness". Berdasarkan definisi ini, penelitian pengembangan yang dibedakan dari pengembangan pembelajaran sederhana, diartikan sebagai studi yang sistematis untuk merancang, mengembangkan, dan mengevaluasi program, proses, dan hasil pembelajaran yang harus memenuhi kriteria konsistensi dan efektivitas internal, penelitian pengembangan adalah kegiatan pengumpulan, pengolahan, analisis dan penyajian data yang dilakukan secara sistematis [7] dan obyektif disertai dengan kegiatan mengembangkan atau menghasilkan suatu produk dan menguji keefektifan produk yang ada untuk menyelesaikan suatu masalah yang dihadapi, berdasarkan pendapat diatas dapat Dikatakan bahwa penelitian dan pengembangan di bidang pendidikan merupakan jenis penelitian yang bertujuan untuk mengembangkan sekaligus memvalidasi produk pendidikan dan pembelajaran [8], maka produk penelitian jenis ini diharapkan dapat digunakan untuk meningkatkan dan mengembangkan mutu pendidikan dan pembelajaran [9].

\section{Hasil dan Pembahasan}

Hasil dari penelitian ini yaitu diciptakan Game edukasi yang mensimulasikan penyemprotan cairan desinfektan, game edukasi yang diciptakan berbasis android, game yang berisikan prosedur penyemprotan disinfektan. Maka game edukasi yang diciptakan memberikan pemahaman kepada pengguna tentsng prosedur yang harus dilakukan sebelum maupun sedang melakukan penyemprotan cairan desinfektan. Game edukasi yang terdiri dari dua level pada level pertama pengguna akan diminta untuk memahami bahan-bahan atau zat yang akan dicampurkan untuk membuat cairan desinfektan [10], selanjutnya pada level kedua terdapat dua babak, dimana pada babak pertama pengguna akan melakukan permainan menembaki karakter virus kecil yang bermunculan, setiap kali tembakan mengenai virus maka pengguna akan mendapatkan tambahan nilai, jika nilai yang didapatkan sudah mencapai 100 maka pengguna akan masuk pada babak kedua [11]. Pada babak kedua pengguna akan melawan boss virus yang berukuran besar yang menyerang secara brutal, pada babak kedua ini pengguna harus bisa menghindari serangan dari boss virus dan sembari terus menembaki boss virus, apabila pengguna gagal dalam menyelesaikan setiap level, maka pengguna dapat mengulanginya lagi atau kembali ke menu utama.

\section{Pengembangan Game}

Research and Development merupakan metode penelitian yang digunakan untuk menghasilkan produk tertentu dan menguji keefektifan produk tersebut [12], menghasilkan produk tertentu digunakan penelitian yang bersifat analisis kebutuhan dan untuk menguji keefektifan produk maka diperlukan penelitian untuk menguji keefektifan produk tersebut, langkah-langkah penelitian dan pengembangan dengan 5 tahapan yang sistematis [13].

Pada tahap pertama, dalam pembuatan game dibutuhkan proses analisis, untuk mengetahui bagaimana GUI yang telah dirancang melalui storyboard system yang termuat dalam game [15]. Berikut tampilan storyboard system game:

Tabel 2 Tabel Storyboard 


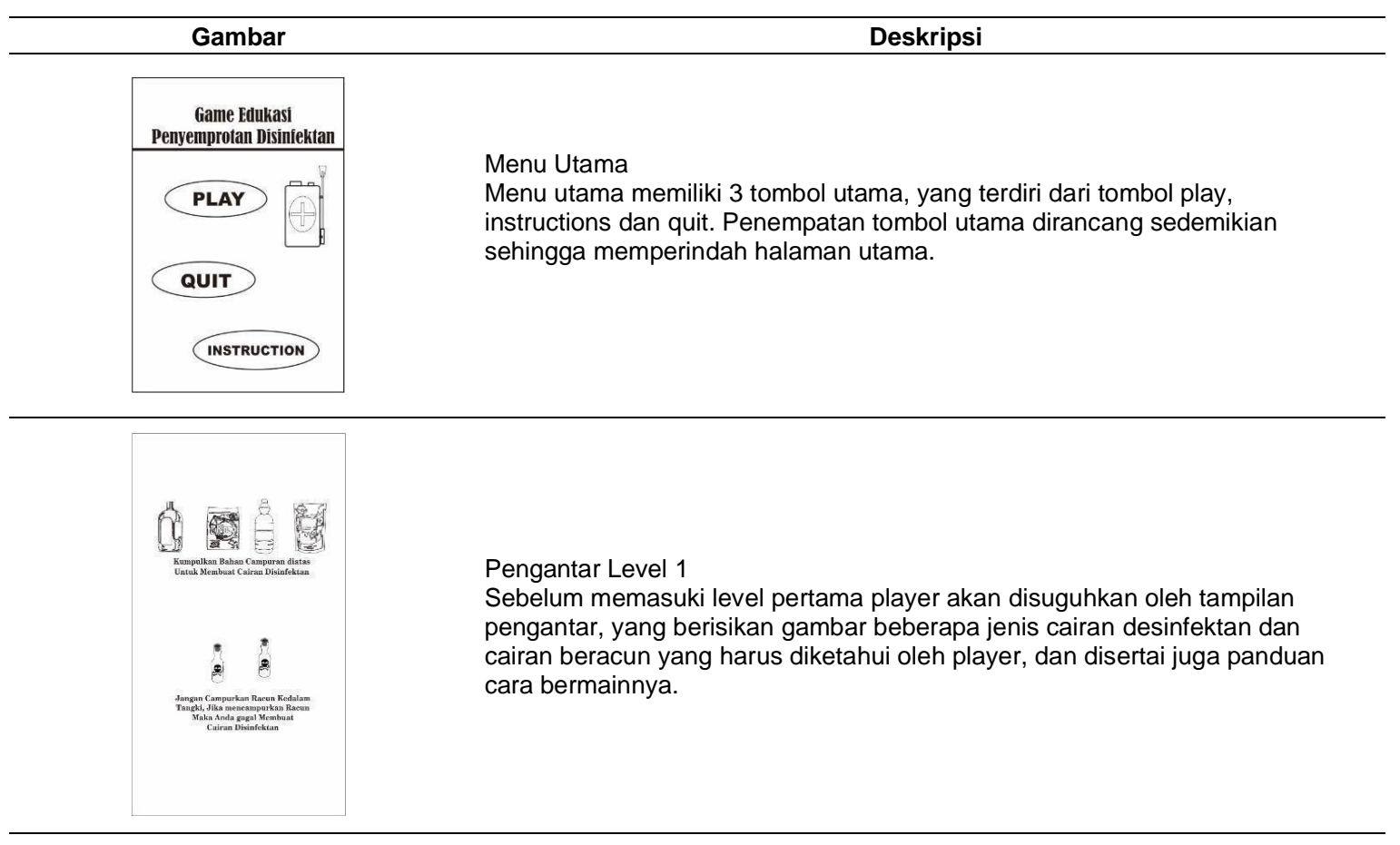

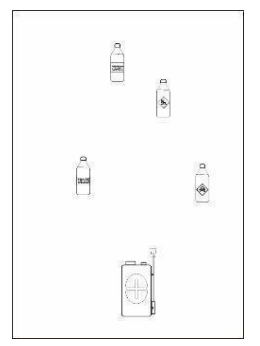

Level 1

Pada level pertama player diminta untuk menangkap cairan disinfektan dengan tabung penyemprot yang berjatuhan dari atas, dalam hal ini player harus mendapatkan seluruh cairan desinfektan untuk melanjutkan ke level selanjutnya, dan player tidak boleh menangkap cairan racun karena jika player menangkap cairan racun maka permainan akan gagal.

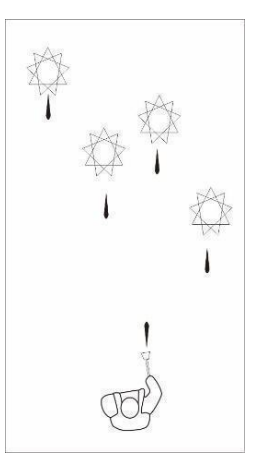

Level 2

Pada level kedua yang merupakan level terakhir dari game edukasi ini, dimana pada level kedua ini player akan diminta untuk menembaki virus-virus yang beterbangan, dan diusahakan tidak terkena paparan dari virus, jika terkena paparan maka darah player akan berkurang sedikit demi sedikit dan permainan pun gagal

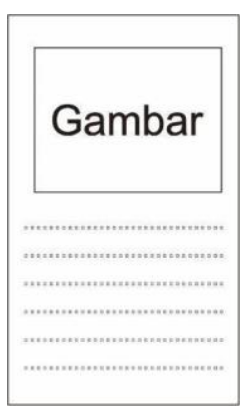

panel finish

Disaat player memainkan game kemudian player tersebut berhasil menyelesaikan misi maka akan muncul panel yang berisi bahwa player telah menyelesaikan permainan. Dan jika gagal menyelesaikannya maka yang muncul adalah panel gagal 
Vol. 5, No. 2, Juni 2021, $166-175$

E-ISSN: 2548-3412

\section{Desain Produk}

Game ini akan menggunakan karakter dua dimensi (2D) yang di desain menggunakan aplikasi desain grafis Corel Draw :

Desain player pada level pertama nampak pada Gambar 1

Sumber: Hasil Penelitian (2021)

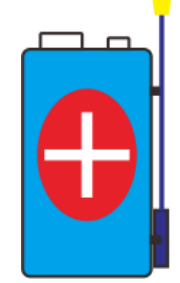

Gambar 1 Gambar player level 1

Desain karakter player pada level kedua menggunakan karakter pada gambar 2.

Sumber: Hasil Penelitian (2021)

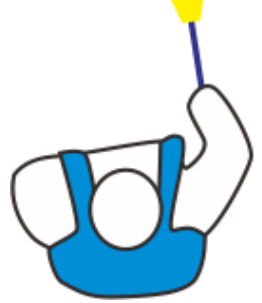

Gambar 2 Gambar player level 2

Desain objek enemy yang berperan sebagai virus dan cairan desinfektan menggunakan karakter yang nampak pada gambar 3 .

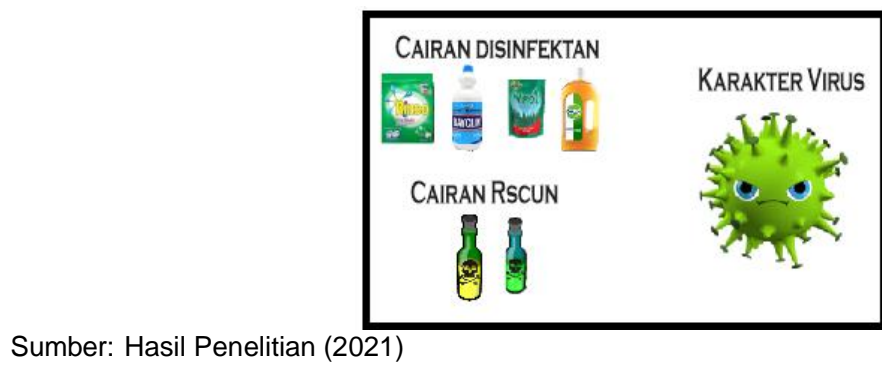

Gambar 3 Gambar karakter Enemy

\section{Pengembangan Produk}

Pada tahap pengembangan produk ini adalah proses pembuatan dalam game, di dalam unity membuat sebuah scene dengan mengatur canvas, camera, membuat animasi [10], membuat coding menggunakan C\# script. 
Sumber: Hasil Penelitian (2021)

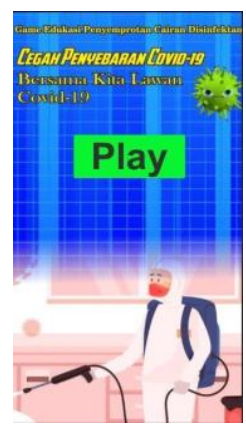

\section{Gambar 4 Gambar Menu Utama}

Di awal permainan pemain langsung masuk pada menu utama yang hanya terdapat judul game dan satu tombol play untuk memualai permainan.

Sumber: Hasil Penelitian (2021)

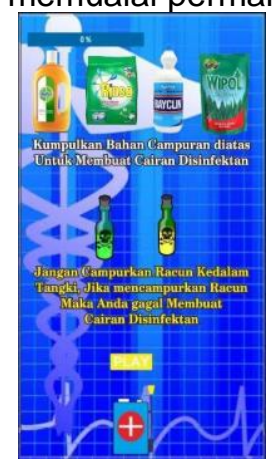

Gambar 5 Gambar Instruksi Level 1

Pada awal permainan level pertama player disuguhkan oleh tampilan pengantar, yang berisikan gambar beberapa jenis cairan desinfektan dan cairan beracun yang harus diketahui oleh player, dan disertai juga panduan cara bermainnya dengan satu tombol play untuk memulai permainan.

Sumber: Hasil Penelitian (2021)

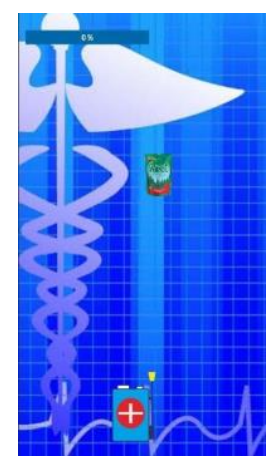

\section{Gambar 6 Gambar Gameplay Level 1}

Pada level pertama player dapat menangkap cairan disinfektan dengan menggerakan tabung penyemprot dengan menggerakkannya kekiri dan kekanan, dalam hal ini player harus mendapatkan seluruh cairan desinfektan untuk melanjutkan ke level selanjutnya, dan player tidak boleh menangkap cairan racun karena jika player menangkap cairan racun maka permainan akan gagal. 
Vol. 5, No. 2, Juni 2021, $166-175$

E-ISSN: 2548-3412

Sumber: Hasil Penelitian (2021)

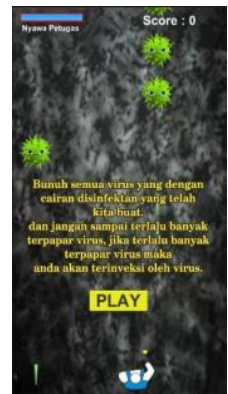

Gambar 7 Gambar instruksi level 2

Pada awal permainan level kedua player disuguhkan oleh tampilan pengantar, yang berisikan instruksi permainan yang dilakukan dalam level kedua ini, dan disertai juga panduan cara bermainnya dengan satu tombol play untuk memulai permainan.

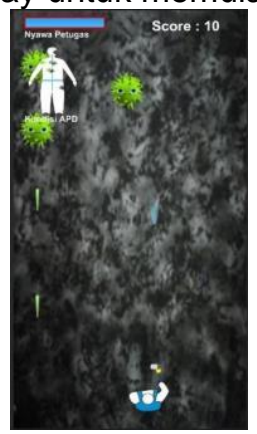

Sumber: Hasil Penelitian (2021)

\section{Gambar 8 Gambar Gameplay level 2}

Pada level kedua pemain harus membunuh virus yang bermunculan, dan menghindari tembakan virus dengan menggerakan karakter ke berbagai arah.

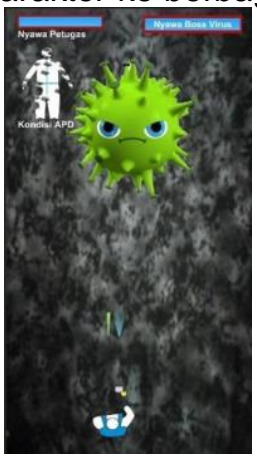

Sumber: Hasil Penelitian (2021)

Gambar 9 Gameplay level 2 babak 2

Masih pada level dua, namun setelah pemain berhasil mendapatkan score 100, maka akan muncul boss virus yang besar dan menembaki player, dan pada babak kedua si level dua ini pemain harus bisa membunuh virus dengan cepat jangan sampai nyawa player habis. 
Sumber: Hasil Penelitian (2021)

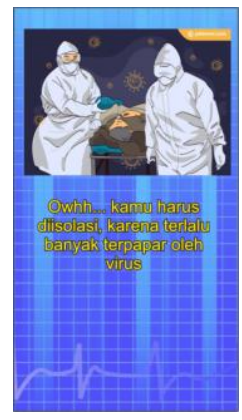

\section{Gambar 10 Gambar Misi Gagal dan Berhasil}

Pada akhir permainan akan muncul salah satu dari hasil yang akan didapat, jika pemain gagal membunuh virus dan nyawa player habis maka akan muncul panel gagal bisa dilihat pada Gambar 10 , dan jika pemain berhasil mengalahkan seluruh virus dan boss virus maka akan muncul misi berhasil bisa dilihat pada Gambar 11.

Sumber: Hasil Penelitian (2021)

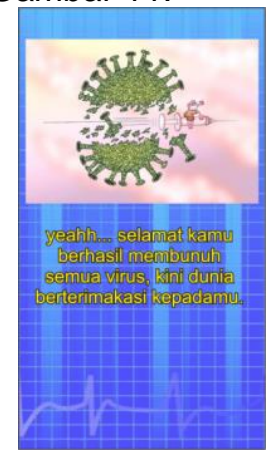

Gambar 11 Gambar misi Berhasil

\section{Kesimpulan}

Teknologi yang berkembang saat ini sejak awal pengembangannya telah banyak diimplementasikan ke dalam dunia pendidikan, tidak terkecuali banyaknya game developer membangun sebuah aplikasi yang bermuatan edukasi. Jika dilihat dari tujuannya aplikasi tersebut diperuntukkan sebagai sarana hiburan, akan tetapi tidak semua aplikasi yang dibangun mengandung unsur edukasi seutuhnya. Adapun kesimpulan dari penelitian ini adalah:

Berdasarkan hasil dari uji hipotesis, dengan dikembangkannya simulasi penyemprotan berbasis game edukasi 2D dapat mendukung dalam upaya mengoptimalisasi pencegahan penyebaran covid-19

Dengan mengacu pada hasil dari pembahasan, bahwa dengan mengoptimalkan tools pada aplikasi Unity 3D simulasi penyemprotan cairan desinfektan berbasis game edukasi 2D dapat mampu dikembangkan.

\section{Referensi}

[1] I. Nozomi, "APLIKASI GAME EDUKASI PADA ANAK USIA 5 SAMPAI 10 TAHUN DENGAN METODE IMAGE MANIPULATION," J. Inf. Technol. Comput. Sci., vol. 1, no. 2, pp. 124-131, 2018.

[2] O. Nurdiawan, I. Ali, C. L. Rohmat, and A. R. Rinaldi, "InfoTekJar: Jurnal Nasional Informatika dan Sistem Kendali Sensor Tanah Sebagai Pemonitor Tingkat Kelembaban Media Tanam Padi," Nas. Inform. dan Teknol. Jar., vol. 1, pp. 0-4, 2020.

[3] D. L. Fithri and D. A. Setiawan, "ANALISA DAN PERANCANGAN GAME EDUKASI SEBAGAI MOTIVASI BELAJAR UNTUK ANAK USIA DINI," SIMETRIS, vol. 8, no. 1, pp. 225-230, 2017.

[4] A. V. Vitianingsih, "Game Edukasi Sebagai Media Pembelajaran Pendidikan Anak Usia Dini,” J. Inf., vol. 1, no. 1, pp. 25-32, 2016. 
[5] N. Mona, "Konsep Isolasi Dalam Jaringan Sosial Untuk Meminimalisasi Efek Contagious ( Kasus Penyebaran Virus Corona Di Indonesia)," J. Sos. Hum. Terap., vol. 2, no. 2, pp. 117-125, 2020

[6] O. Nurdiawan, F. A. Pratama, D. A. Kurnia, Kaslani, and N. Rahaningsih, "Optimization of Traveling Salesman Problem on Scheduling Tour Packages using Genetic Algorithms," J. Phys. Conf. Ser., vol. 1477, no. 5, pp. 0-6, 2020, doi: 10.1088/17426596/1477/5/052037.

[7] D. R. Buana, "Analisis Perilaku Masyarakat Indonesia dalam Menghadapi Pandemi Virus Corona (Covid-19) dan Kiat Menjaga Kesejahteraan Jiwa?," SALAM; J. Sos. Budaya Syar-i, vol. 7, no. 3, pp. 216-226, 2020.

[8] S. Setiati and M. K. Azwar, "COVID-19 and Indonesia," Acta Med Indones - Indones J Intern Med, vol. 52, no. 1, pp. 83-89, 2020.

[9] O. Nurdiawan, F. A. Pratama, D. A. Kurnia, Kaslani, and N. Rahaningsih, "Optimization of Traveling Salesman Problem on Scheduling Tour Packages using Genetic Algorithms," J. Phys. Conf. Ser., vol. 1477, no. 5, 2020, doi: 10.1088/17426596/1477/5/052037.

[10] I. Rohmawati, Sudargo, and I. Menarianti, "Pengembangan Game Edukasi Tentang Budaya Nusantara 'Tanara' Menggunakan Unity 3D Berbasis Android," J. SITECH Sist. Inf. dan Teknol., vol. 2, no. 2, pp. 173-184, 2019.

[11] A. F. Adiqro, "Aplikasi Pembelajaran Menulis Permulaan Berbasis Android Menggunakan Unity 2D,” J. Inf. Technol., vol. 6, no. 1, pp. 53-62, 2018.

[12] I. H. Putri, "Pengembangan Game Edukasi 2D Platformer 'Petualangan Rama Sinta ' Berbasis Android," J. Syst. TI POLINEMA, vol. 2, no. 1, 2016.

[13] O. Nurdiawan, D. A. Kurnia, D. Solihudin, T. Hartati, and T. Suprapti, "Comparison of the K-Nearest Neighbor algorithm and the decision tree on moisture classification," IOP Conf. Ser. Mater. Sci. Eng., vol. 1088, no. 1, p. 012031, 2021, doi: 10.1088/1757899x/1088/1/012031.

[14] L. Mukarromah, F. S. Siskawati, P. Matematika, U. I. Jember, and N. Normal, "PENGEMBANGAN GAME EDUKASI ' HOTSNAKER' BERBANTUAN VLOG SEBAGAI ALTERNATIF MEDIA PEMBELAJARAN MATEMATIKA DI ERA NEW," Konf. Nas. Pendidik. I, vol. 40, 2020.

[15] A. Mar, A. P. Armin, and E. D. Hartono, "Game Edukasi Tembung Aran Menggunakan Tools Engine Game Unity," BINA Insa. ICT J., vol. 7, no. 2, pp. 135-144, 2020. 